\title{
Community Meetings in Early Medieval Castile
}

\author{
JULIO ESCALONA*
}

\section{Introduction}

This chapter is an exploration of meetings held by local communities in the territory of the County of Castile between the 9th century and AD 1038, with a primary focus in the 10th century. In this period, Castile was an administrative district of the Asturian kingdom and its rulers were titled counts, denoting their subjection to the kings, even though their theoretically delegated power was exercised with very little direct royal interference, by contrast to the core regions of Oviedo and León where royal action was much more conspicuous. This began to change only in the second decade of the 11th century, in the context of the build-up of the Navarran dynasty's access to power in León. Aside from several military episodes and a very few occasions in which there was direct political action by the kings within the Castilian territory, the period is one in which the counts can be seen as the region's highest effective political power. ${ }^{1}$

Local communities are prominent in pre-1038 Castilian charters. Their members feature in written deeds as donors, vendors, buyers, witnesses, sureties, supporters and so on, and even collective agency carried out by whole local communities as such is sometimes recorded. Many of those actions clearly require the sort of consensus, planning and organisation that can be expected to emerge from local meetings. However, the documentary visibility of Castilian communities and their members is not paralleled by that of their meetings, which remain remarkably elusive in the charters of this period. This is largely due to the predominantly monastic nature of the preserved

\footnotetext{
* In this chapter, each charter is cited by the abbreviated edition, followed by numbering within and the year of issue between brackets. See the abbreviation list at the end. The chapter was developed within the framework of and with financial support from the research projects HAR2010-21950-C03-01(Plan Nacional de I+D+i) and HAR2013-47889-C3-2-P (Programa Estatal de Investigación Científica y Técnica de Excelencia) funded by the Spanish Government's Plan Nacional de I+D+i. During the various phases of the research for, I have benefited from comments and criticism from a number of colleagues, most substantially Isabel Alfonso, Wendy Davies, Álvaro Carvajal, Juan Antonio Quirós and Alfonso Vigil-Escalera, as well as from the participants at the London conference. I must also thank Andrew Reynolds, Stuart Brookes, Barbara Yorke and Jayne Carroll for their editorial encouragement and patience. Although I owe gratitude to all of them for helping me improve the text and avoid a good many errors, of course I am solely responsible for any shortcomings.

${ }^{1}$ For detailed narrative of the political history of the Castilian county, see G. Martínez Díez, El Condado de Castilla (711-1038). La Historia frente a la leyenda, 2 vols (Valladolid, Junta de Castilla y León, 2004).
} 
charter collections, as I discuss below. Other data sources have little to add to this picture. Narrative sources of this period are almost totally absent from Castile, and pretty rare for the rest of the kingdom. Place-names are of limited help too, mainly because, unlike in other contexts discussed in this volume, in Castile words for 'meeting-place' almost never occur as either modern or old place-names. ${ }^{2}$ Likewise, the input from archaeology is seriously limited so far. It is only very recently that early medieval peasant settlements have begun to be investigated in depth, but the available data rarely permit any detailed-even if extremely fragmentary-topographical analysis. There are exceptions, such as the early medieval villages excavated in the Madrid region, ${ }^{3}$ or, within my study area, the uniquely exhaustive excavation of the village of Zaballa, ${ }^{4}$ but the definition of potential assembly sites from those records remains largely hypothetical.

For these reasons, the present chapter is a preliminary exploration, aiming to provide insights into what might be expected from a more thorough investigation of early medieval Castilian local meetings. I am concerned here with three, very basic questions - did local communities hold meetings in early medieval Castile? If so, what for? And where? - and an additional, less basic one: to what extent did local communities engage in meetings at a supralocal scale? In doing so, I will concentrate on discussing those elements in the documentary sources that can help develop a picture of what local assemblies were and how they worked.

\section{Did Local Communities Hold Meetings in Early Medieval Castile?}

The village community has long been considered the quintessential form of social organisation throughout early medieval north-western Iberia, even if alternative, more dispersed farm-type patterns have been suggested, especially for the northernmost mountainous areas. ${ }^{5}$ Since the turn of the $21^{\text {st }}$ century, archaeology has begun to define the process of creation of village-type settlements following the collapse of Roman settlement structures, and in doing so, is challenging the inherited view that villages only became fully consolidated with the emergence of the local parish system in the late 10th and 11th centuries. ${ }^{6}$ Castile fits this general picture, although archaeological

\footnotetext{
${ }^{2}$ Cf. M. P. Álvarez Maurín, Diplomática asturleonesa. Terminología toponímica (León, Universidad de León, 1994).

${ }^{3}$ A. Vigil-Escalera Guirado, 'Granjas y aldeas altomedievales de la meseta (450-800). Configuración espacial, socioeconómica y política de un territorio rural al norte de Toledo' (unpublished DEA thesis, Universidad del País Vasco, 2007); A. Vigil-Escalera Guirado, 'Granjas y aldeas altomedievales al norte de Toledo (450-800 d.C.)', Archivo Español de Arqueología, 80 (2007), 239-84; A. Vigil-Escalera Guirado, 'Las aldeas altomedievales madrileñas y su proceso formativo', in J. A. Quirós Castillo (ed.), The Archaeology of Early Medieval Villages in Europe (Bilbao, Universidad del País Vasco, 2009), pp. 315-39; J. A. Quirós Castillo and A. Vigil-Escalera Guirado, 'Networks of Peasant Villages between Toledo and Velegia Alabense, Northwestern Spain (V-Xth Centuries)', Archeologia Medievale, 33 (2006), 79-128; Quirós Castillo (ed.), The Archaeology of Early Medieval Villages; J. A. Quirós Castillo, 'Arqueología del campesinado altomedieval: las aldeas y las granjas del País Vasco', in Quirós Castillo (ed.), The Archaeology of Early Medieval Villages, pp. 385-403.

4 J. A. Quirós Castillo (ed.), Arqueologia del Campesinado Medieval: La Aldea de Zaballa (Bilbao, Universidad del País Vasco, 2012).

5 J. Á. García de Cortázar y Ruiz de Aguirre, La sociedad rural en la España medieval (Madrid, Siglo XXI, 1988), pp. 7-26; C. Díez Herrera, La formación de la sociedad feudal en Cantabria (Santander, Universidad de Cantabria, 1990). An overview can be found in Vigil-Escalera Guirado, 'Granjas y aldeas altomedievales'; see also the essays collected in Quirós Castillo (ed.), The Archaeology of Early Medieval Villages.

${ }^{6}$ Cf. J. Á. García de Cortázar y Ruiz de Aguirre, La sociedad rural, pp. $17 \mathrm{ff}$.
} 
research has been significantly less intense there than in other Iberian regions, and the material evidence for early medieval settlement is consequently much thinner.

Archaeological sites of this kind are usually equated to the entities that feature in the 9th- to 12th-century Latin written records as villa, -ae, a term that is normally translated as Spanish aldea. Consequently, the sites labelled aldeas, whose materiality is known to us almost exclusively through archaeological records, become definedand explained - by reference to forms of sociability that are known almost exclusively from the written sources or ethnographical parallels. It is not within the scope of this chapter to discuss the disadvantages of this approach or to what extent it is methodologically valid. ${ }^{7}$ I aim only to remark that among the features of community sociability, local assemblies have long been recognised as a key aspect, but one that hitherto has largely resisted archaeological definition.

Nevertheless, it is widely accepted that in northern Iberia, throughout the Middle Ages, getting together was the normal way for communities to deal with their everyday affairs. This is rooted in the works of legal historians who, since the 19th century, have tried to define the origins and development of the medieval municipalities as the immediate precedent of modern ones. ${ }^{8}$ Those authors took as their starting point the better-known local governments of the central and later medieval period. By that time, local institutions had achieved a high degree of formalisation, which sometimes included a formal recognition of relative political autonomy from the king or lord, as expressed in local bye-laws, the so-called fueros, although those were more commonly granted to towns and major settlements. ${ }^{9}$

Working from that perspective, legal historians also tried to trace the origins of central medieval forms of local government and, in doing so, they emphasised the importance of early medieval local community assemblies as the institutional precedents of the central medieval municipalities. The lack of formal recognition from higher powers (mainly the king) in that period was singled out as the key factor in differentiating early medieval assemblies from later local governments, which led early medieval communities to be labelled 'imperfect' or 'primitive'. ${ }^{10}$ Such a teleological approach implied that the early medieval assemblies were not really understood in themselves, within their own time and rationale, but interpreted as 'imperfect' or 'undeveloped' forms of their successors. This not only played down whatever political significance they had but, importantly, it framed them within a general conception of

\footnotetext{
${ }^{7}$ See critical discussions in J. A. Quirós Castillo, 'Las aldeas de los historiadores y de los arqueólogos en la Alta Edad Media del norte peninsular', Territorio, sociedad y poder, 2 (2007), 63-86 and J. J. Larrea Conde, 'De la invisibilidad historiográfica a la apropiación del territorio: aldeas y comunidades en la España cristiana (siglos X y XI)', in J. I. De la Iglesia Duarte (ed.), Cristiandad e Islam en la Edad Media hispana (Logroño, Instituto de Estudios Riojanos, 2008), pp. 169-207, and on the sensitive interface between historians and archaeologists, see J. Escalona, 'The Early Castilian Peasantry: An Archaeological Turn?', Journal of Medieval Iberian Studies, 1-2 (2009), 119-45.

${ }^{8}$ E. Hinojosa y Naveros, 'Orígenes del régimen municipal en León y Castilla', in E. Hinojosa (ed.), Estudios sobre la historia de derecho español (Madrid, Imprenta del Asilo de Húerfanos del Sagrado Corazón de Jesús, 1903), pp. 5-70; P. Merêa, 'Sobre as origens do concelho de Coimbra (estudo histórico-jurídico)', Revista Portuguesa de História, 1 (1941), 49-69; C. Sánchez-Albornoz, Ruina y extinción del municipio romano en España e instituciones que lo reemplazan (Buenos Aires, Instituto de Historia de la Cultura Española Medioeval y Moderna, 1943); J. M. Font i Rius, Orígenes del régimen municipal de Cataluña (Madrid, Instituto Nacional de Estudios Jurídicos, 1946); M. C. Carlé, Del concejo medieval castellano-leonés (Buenos Aires, Instituto de Historia de España, 1968). A brief summary can be found in L. García de Valdeavellano, Curso de Historia de las Instituciones Españolas. De los orígenes al final de la Edad Media (Madrid, Revista de Occidente, 1968), pp. 532-3.

${ }^{9}$ Carlé, Del concejo medieval castellano-leonés, pp. 31-42.

${ }^{10}$ Carlé, Del concejo medieval castellano-leonés; García de Valdeavellano, Curso, p. 538.
} 
power relationships that only worked top down: all forms of power derived from the highest sphere (the king) and flowed downwards by formal delegation. Local communities were obviously at the opposite end of the power scale from the king. Their sphere of competence and the contents of their meetings were seen as limited to 'practical' everyday affairs, as opposed to the 'politicised' notion of local government embodied by the central medieval municipalities.

In searching for the origins of the medieval local governments, legal historians tended to start with the Visigothic period. The extensive body of legislation that has survived from that time contains precious little information about the governance of rural localities, which suggests that this was not a cause of great concern for the legislators. In the 7th century, Isidore of Seville referred in his Etymologies to the existence of public meetings of the rural population held in agreed places with the purpose of dealing with local affairs: Conpita sunt ubi usus est conuentus fieri rusticorum; et dicta conpita quod loca multa in agris eodem conpetant; et quo convenitur a rusticis ['Compita are places where peasants use to assemble, and they are called compita because they gather there from many places, as agreed by the peasants']. ${ }^{11}$ The term compitum originally referred to a crossroad, but in this context can be taken as a generic word for 'meeting-place', ${ }^{12}$ while conuentus is used by Isidore elsewhere to refer generally to any kind of meeting. ${ }^{13}$ It seems something of an overinterpretation to try to infer from this passage any formal institutional character for those peasant meetings. Isidore's wording seems to imply instead a rather autonomous form of organisation (they meet at wherever they agree), with no formal involvement from any higher power. It is probably to the same kind of bottom-up organised assemblies that the Liber Iudiciorum refers in its scant references to the conuentus publicus uicinorum, a term whose institutional character has been considerably exaggerated in the past. The clearest reference occurs in relation to the obligation of whoever finds stray animals to report them to the authorities: Caballos vel animalia errantia liceat occupare, ita ut qui invenerit denuntiet aut sacerdoti aut comiti aut iudici aut senioribus loci aut etiam in conventu publico vicinorum. Quod si non denuntiaverit, furis damnum habebit. Similis et de aliis rebus ordo manebit ['It shall be lawful to take up horses, or any other animals, that have strayed; but he who does so, must immediately give notice of the fact to the bishop, the governor, the judge, the other authorities of the district, or to a public assembly of the neighbors. If said party should not give such notice, he shall incur the penalty of theft. A similar rule shall apply to other property taken up under the same circumstances']. ${ }^{14}$

The local meeting is mentioned here as just another way of ensuring that the finding of animals is legitimised either by an authority or by general knowledge (hence the term publicus). Nowhere in the Visigothic Code is a proper legal definition of the rural conuentus to be found, which seems to support the idea that such local meetings were not regarded as part of the state institutional apparatus. Elsewhere in the code there are mentions of local people taking joint decisions about everyday issues, such as

11 Isidore of Seville, Etymologiae in J. Oroz Reta and M. A. Marcos Casquero (ed. and trans.), Etimologías de San Isidoro de Sevilla (Biblioteca de Autores Cristianos, Madrid, 2009), XV, $2,15$. English translation is my own.

12 P. Cullen, D. N. Parsons and R. Jones, Thorps in a Changing Landscape (Hatfield, University of Hertfordshire Press, 2011), p. 159.

${ }^{13}$ Isid. Etym., VI, 16, 13.

${ }^{14}$ Leges Visigothorum, in K. Zeumer (ed.) Monumenta Germaniae historica, Legum sectio 1, Leges nationum Germanicarum, 1 (Hannover: Hahn, 1902), VIII, V, 6. English transl. from S. P. Scott (ed. and trans.), The Visigothic Code (Forum judicum) (Boston, Boston Book Company, 1910), p. 301. See also Leges Visigothorum, VIII, IV, 14 and IX, I, 9. 
property boundaries, the management of common land and resources, the regulation of husbandry or the punishment of wrongdoers. We might expect that to have happened in the context of local meetings, but the sources are hardly explicit about it. It rather seems that many aspects of local life were organised ad hoc, without formal involvement from the state or delegation of authority, and that such arrangements were taken for granted by everyone as a normal aspect of rural local life.

For the same reasons, it seems a rather formalistic exercise to conceive of the local assemblies of the post-Visigothic period as the institutional successors of a legal figure called conuentus publicus uicinorum. ${ }^{15}$ Most of northern Iberia underwent an intense collapse of state organisation during the 8th century, with a general demise of higher administrative structures. If peasants in the Visigothic period would normally deal with their common affairs in local assemblies, a similar practice can be expected to have worked all the more easily in the absence of a comparably complex system of governance. This, however, does not mean that such assemblies would be exclusively oriented to practical issues and totally devoid of 'political' contents, as traditional legal historians would defend; quite the opposite, as we shall see.

There is, nevertheless, a noticeable gap in information for the 8th to 10th centuries. Only from the 10th century on do local assemblies seem to emerge in the written sources, at the pace that rural settlements gradually joined the process of institutionalisation of local governance that ultimately gave way to the central medieval municipalities. Certainly, this process was more intense - hence visible - in the case of towns, whose local governments became increasingly regulated from the 11th century onwards, ${ }^{16}$ but it also took place at village level. Thus, in the central and later Middle Ages, a standard picture arises of a network of local communities whose formal members (heads of households with community membership) held periodic plenary meetings, usually at or outside the parish church, summoned by local officers (alcaldes) who were also the community's acknowledged representatives before seigneurial or royal authorities. A document of 1443 from the small town of Peñafiel paints a vivid picture: 'we, the council of the knights and esquires of the town of Peñafiel, assembled together inside the church of San Esteban of the aforesaid town, to the sound of bells as it is our custom when we gather'. ${ }^{17}$ Between those two extremes - the Visigothic and the central Middle Ages - the Castilian comital period remains a darker area to explore.

\footnotetext{
${ }^{15}$ García de Valdeavellano, Curso, pp. 207-8.

${ }^{16}$ See J. M. Monsalvo Antón, El sistema político concejil. El ejemplo del señorío medieval de Alba de Tormes y su concejo de Villa y Tierra (Salamanca, Universidad de Salamanca, 1988); J. M. Monsalvo Antón, 'Aspectos de las culturas políticas de los caballeros y los pecheros en Salamanca y Ciudad Rodrigo a mediados del siglo XV: violencias rurales y debates sobre el poder en los concejos', in I. Alfonso Antón, J. Escalona and G. Martin (eds), Lucha política: condena y legitimación en la España medieval (Lyon, École Normale Superieure, 2004), pp. 237-96. An institutionalist perspective in F. J. Martínez Llorente, Régimen jurídico de la Extremadura castellana medieval: las Comunidades de Villa y Tierra (s. X-XIV) (Valladolid, Universidad de Valladolid, 1990).

17 nos, el ayuntamiento de los caualleros e escuderos de la villa de Peñafiel, estando ayuntados en nuestro ayuntamiento, dentro en la iglesia de Sant Steuan de la dicha villa, a campana tannida, segunt que lo abemos de uso e de costumbre de nos ayuntar. Cit. F. Miranda García, 'Conflictos sociales y poder concejil en una villa de señorío. Peñafiel (1425-1443)', Historia, Instituciones y Documentos, 33 (2006), $435-56$ at $450-2$.
} 


\section{The Vocabulary of Community Meetings in the County of Castile}

This analysis is based upon a database under development at the Instituto de HistoriaCSIC that is intended to record all charters produced up to AD 1038 within the territory of the County of Castile as it was defined in around 980 (Figure 10.1). In its present state it contains 698 entries, which represent over 95 per cent of all known documents, with a very uneven chronological distribution (Figure 10.2). By excluding obvious forgeries and less reliable pieces, the total figure comes down to 617. The preserved charters are very scarce before 930 , after which there is a noticeable increase. Sixty-one per cent of the whole collection dates to $930 \times 1000$ and 31 per cent to $1001 \times 1038$. A substantial decrease in the late 10th century must also be noted. ${ }^{18}$

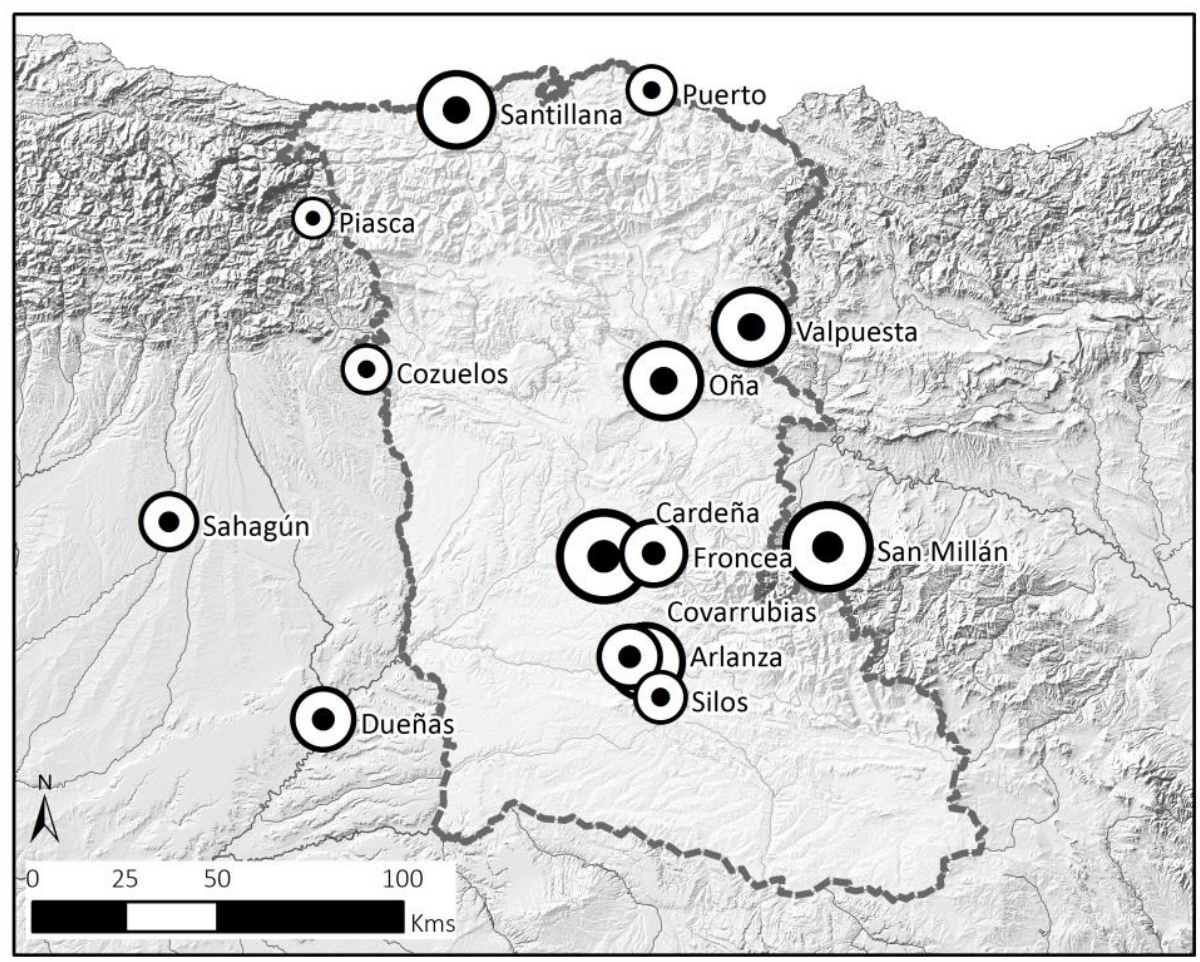

Figure 10.1 Geographical coverage of the database upon which this enquiry is based, showing the territory controlled by the Counts of Castile $c$.ad 980 . Symbols logarithmically scaled to represent the collections' relative significance (Julio Escalona)

As virtually all preserved charters derive from monastic collections and arguably most were produced in monastic scriptoria, we can expect their wording to reflect monastic usage. ${ }^{19}$ This may sometimes affect the vocabulary by which local community meetings

\footnotetext{
${ }^{18}$ A detailed description in J. Escalona, 'La documentación de la Castilla condal: viejos problemas y nuevas perspectivas', in B. Arízaga Bolumburu and J. Á. Solórzano (eds), Mundos medievales. Espacios, sociedades y poder. Homenaje al Profesor José Ángel García de Cortázar y Ruiz de Aguirre (Santander, Universidad de Cantabria, 2012), pp. 473-88.

${ }^{19}$ The nature of those sources is much more complex, though, including the existence of charters or even whole sets of charters of lay provenance within the monastic collections. See A. Kosto, 'Sicut mos esse solet: Documentary Practices in Christian Iberia, c. 700-1000', in W. Brown, M. Costambeys, M. Innes and A. Kosto (eds), Documentary Culture and the Laity in the Early Middle Ages (Cambridge, Cambridge University Press, 2012), pp. 259-82; W. Davies, 'Local Priests and the Writing of Charters in Northern Iberia in the Tenth Century', in J. Escalona and H. Sirantoine (eds), Chartes et cartulaires
} 
were referred to in those texts, because the notion of communitas can be applied as much to the members of rural localities as to those of monastic communities, and therefore, ecclesiastical vocabulary may colour the activities of the laity. Our database contains a total of 122 occurrences of groups of people acting collectively, of which sixty-nine are largely formulaic references to monastic communities or ecclesiastical assemblies. ${ }^{20}$ Eight more cases clearly refer to judicial assemblies not necessarily related to local communities, ${ }^{21}$ which leaves a modest corpus of forty-five references to local community meetings for discussion, although such a small sample precludes statistical analysis.

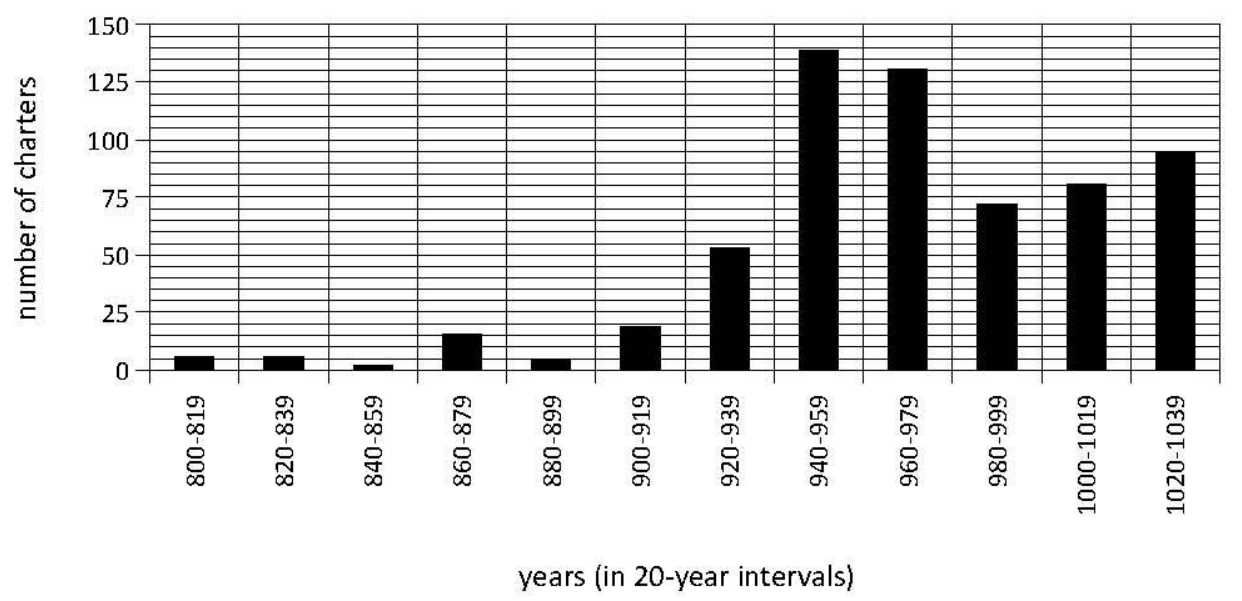

Figure 10.2 Chronological distribution of the Castilian charters up to 1038 , by 20 -year intervals (Julio Escalona)

The range of terms employed is quite broad. Sometimes these are words that refer specifically to assemblies, such as collegium, concilium, congregatio, collatio, communitas or capitulo, while others are mentions of collectives or individuals in the plural, the context providing evidence of collective action, for example: habitantes, totos, omnes, homines, vicini, populus and populatores. Among the first group, references that clearly relate to monastic assemblies are abundant; much less so in the second, except for generic collective references such as totos, omnes or, less frequently, habitantes, which occur indistinctively in both contexts.

Figure 10.3 represents a more nuanced breakdown of this convergence of the ecclesiastical and the secular in the most used terms for meetings. Words like collatio or congregatio are used exclusively of clerical gatherings. With a few remarkable exceptions, the same is true for the much more frequent collegium. At the opposite end,

comme instruments de pouvoir. Espagne et Occident chrétien (VIIIe-XIIe siècles) (Toulouse, Université de Toulouse-Le Mirail-CSIC, 2013), pp. 29-43.

${ }^{20}$ For instance, Cardeña, 50 (945): tibi patri nostro domno Stefanus, abba, uel omne collegium fratrum cohabitantes in domum Sanctorum Apostolorum Petri et Pauli, qui est situm cenobium locum Caradigna ['to you our father lord Stefanus, abbot, as well as the whole college of brethren dwelling in the house of the lords Holy Apostles Peter and Paul, monastery that lies in the place called Cardeña'].

${ }^{21}$ Wendy Davies, 'Local Priests and the Writing of Charters in Northern Iberia in the Tenth Century', in Chartes et cartulaires comme instruments de pouvoir. Espagne et Occident chrétien (VIIIe-XIIe siècles), ed. Julio Escalona and Hélène Sirantoine (Toulouse, Université de Toulouse-Le Mirail - CSIC, 2013), pp. 29-43; Isabel Alfonso Antón, 'El formato de la información judicial en la Alta Edad Media peninsular', in Chartes et cartulaires comme instruments de pouvoir. Espagne et Occident chrétien (VIIIe-XIIe siècles), ed. Julio Escalona and Helène Sirantoine (Toulouse, Editions Méridiennes, Université Toulouse le Mirail - CSIC, 2013), pp. 191-218. 
homines is never used for monastic communities, only for secular gatherings. By far the most polysemic term is concilium, which is the standard word designating local communities (thence Cast. concejo, meaning local council), but also refers to judicial courts and, occasionally, ecclesiastical assemblies. Moreover, concilium can designate both a corporate group of persons and the formal assembly in which they gather (so, decisions are taken in concilio). Besides, the secular meaning of concilium comprises different kinds of communities: villages, district centres and towns.
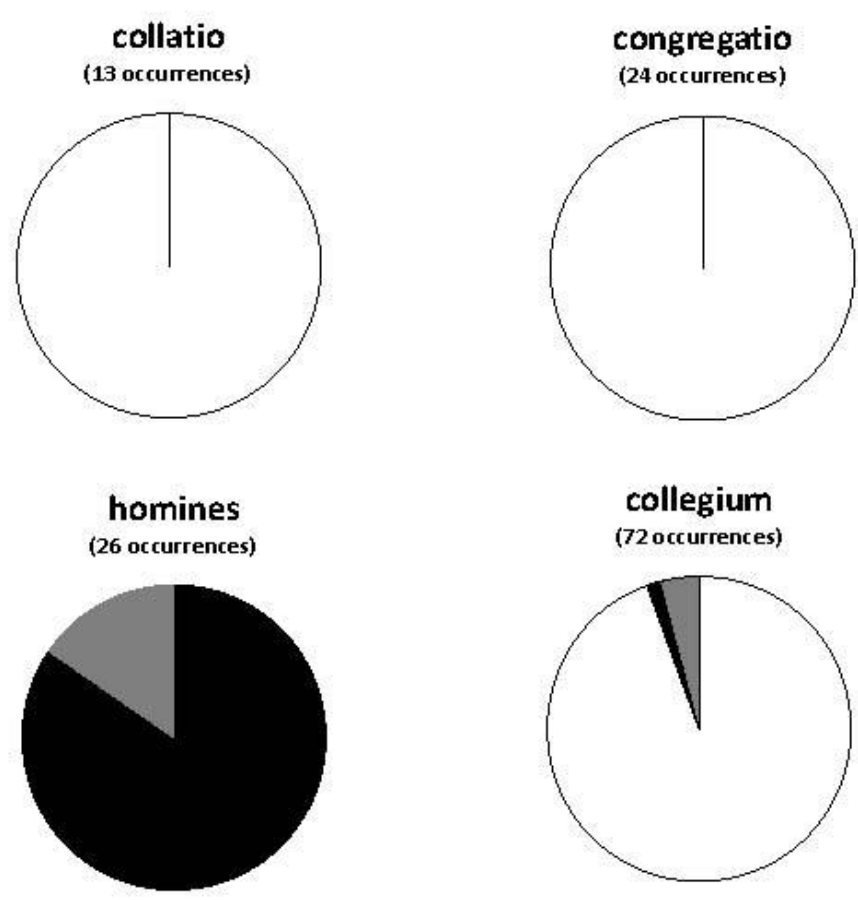

\section{concilium \\ (48 occurrences)}

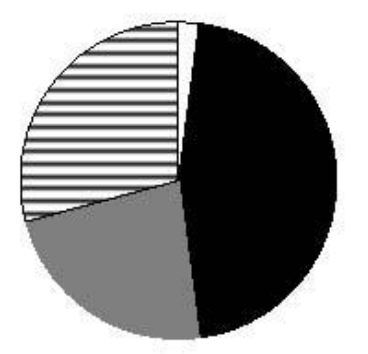

$$
\begin{aligned}
& \text { 口eccle siastical / monastic } \\
& \text { community } \\
& \text { घillage } \\
& \text { town/district centre } \\
& \text { 日 court }
\end{aligned}
$$

Figure 10.3 The vocabulary of community meetings in the Castilian charters (Julio Escalona)

In this discussion, my attention will focus upon this kind of secular assembly, leaving aside strictly clerical or judicial ones, even if allowing for a certain degree of ambiguity in the local character of the latter. Given the monastic bias of the evidence, it is interesting that local communities can nevertheless be seen meeting and/or taking collective action. 


\section{Why Did Local Communities Meet?}

Local communities surely met for a variety of purposes, but not all are recorded in the charters. The diplomatic nature of the sources largely determines which functions of the assembly are most visible. Thus, community meetings are mentioned in charters mostly in relation to property transactions or dispute settlements, and often they occur playing 'diplomatic' roles in the process of charter production, such as witnessing donations. This, of course, may have little to do with the communities' actual priorities. Both property transactions and dispute settlements required the kind of public acknowledgement that a plenary community meeting could provide, but the fact that those actions were enacted before the concilium does not mean that they were the primary reasons for a meeting. Major community concerns, like the management of common resources within the local territory, the regulation of specific aspects of everyday local life, or the celebration of religious festivals, might have been perceived as the real priorities. Yet sadly those rarely emerge from the diplomatic evidence.

\section{Local council as owner of land or commons}

Of all functions, the regulation of access to common resources might well have been the main motive for holding community meetings. ${ }^{22}$ Legal and judicial documents from the 12 th century onwards make clear that a great part of medieval local political life was related to taking and implementing decisions on how and by whom community-held resources were exploited. Additionally, local collective identity was strongly linked to their defence from intruders - whether neighbouring communities or lordly powersand to dealing with conflict between individual and collective interests within the community. However, within the timespan of this study, local communities are rarely seen taking decisions about their commons. Those decisions certainly existed, though, as is indirectly revealed by the formula homines de $X$ designating the inhabitants of a village as collective holders of rights over land, pastures and commons. For example, a 1025 charter mentions property neighbouring the lands of the community of Igollo (iusta terminu de omines de Egollo), ${ }^{23}$ and in 1020 Countess Sancha possessed in the village of Santa María one mill, and one half of another whose other half was collectively owned by the men of Barriales: 'molino integro et alio medio cum homines de Barriales'. ${ }^{24}$ Most unusually, a $944 \times 950$ charter from the Cardeña cartulary presents the whole community of Villabáscones ('nos omnes, id est, de Uilla Uascones') as the patrons of a monastery dedicated to Saint Martin. ${ }^{25}$ It was probably not unusual for some Castilian local communities to build and own local churches that could be described as monasteries. What is striking in this example is that the whole community gathered to enact formally the emancipation of the monastery of San Martín from their hands, from which moment the monastery became an independent local actor and one whose interests sometimes clashed with those of its former patrons. ${ }^{26}$

Mentions of community property can be compared to those of collective rights and obligations. Shared access to common land and natural resources was arguably a

\footnotetext{
${ }^{22}$ On the relevance of common rights management in the definition of Anglo-Saxon local identities, see R. Faith, 'Forms of Dominance and the Early Medieval Landscape', Medieval Settlement Research, 23 (2008), 9-13 and S. Oosthuizen, 'Archaeology, Common Rights and the Origins of Anglo-Saxon Identity', Early Medieval Europe, 18.2 (2011), 153-81.

23 'by the boundaries of the men of Igollo', Santillana2, 35 (1025).

${ }^{24}$ Sahagún2, 407 (1020).

${ }^{25}$ Cardeña, 45 (944-50).

${ }^{26}$ Cardeña, 87 (955); 88 (955); 89 (956).
} 
key factor in the effective workings of local communities, and one that surely demanded the sorts of agreements and decisions that can be expected to be reached in local assemblies. Unfortunately, though, such strictly local affairs rarely made it into the predominantly monastic written records. We can have, nevertheless, a 'negative' glimpse of their functioning by examining those cases in which such collective rights were limited or alienated in any way. For instance, in 864 the monastery of San Félix de Oca was granted a large enclosed space (defesa) of woodland in Bárcena, which comprised a river-stretch within which only the men of the monastery were allowed to fish. The men from the neighbouring villages were banned from fishing, hunting or exploiting the woods in any way: Itaque preter homines de hune [sic] monasterio, alios homines de alias non habeant licentia in ipso rivo infra terminos supradictos piscato preendere, nec aliqua genera occidere in ipsa silva, glandiferos vel aliqua genera arborum que sunt in Barcena ['And that besides the men of the aforesaid monastery, no men from other [villages] may have permission to catch fish within the aforesaid boundaries, nor to cut in those forests any oaks or trees of other kind that there are in Bárcena']. ${ }^{27}$

This can be taken as reflecting, albeit negatively, the otherwise widespread rights that local communities enjoyed over common resources. More explicitly, in 972 the council of Ausín gave the Count of Castile a large stretch of enclosed woodland in exchange for exemption from the obligation to maintain the Count's fortresses: 'We all, the whole council of Ausín, high and low, young and old'; and later on: 'We, the aforesaid men of Ausín'. Here, the dismissal of a portion of commons results from an agreement, although we cannot evaluate how much pressure was put on the community in favour of this solution. ${ }^{28}$

\section{Local council meeting as the context of dispute settlements}

Of the roughly 700 charters of the Castilian comital period, about 10 per cent contain information about disputes and judicial processes. It is often difficult to define the character and scale of these judicial assemblies, but despite the general lack of precision, it is clear that sometimes disputes were dealt with in the context of a local meeting, ${ }^{29}$ even if there was involvement from comital officers or the counts themselves. For example, in 941 a lawsuit has heard 'in the presence of Count Don Fernando and all the judges and a multitude of notables from the council of Burgos', ${ }^{30}$ and in 972 another was held 'in the presence of Count García Fernández and the whole council of the city of Burgos'. ${ }^{31}$ Of course, the town of Burgos was the County's main political centre, so it makes perfect sense to see the counts of Castile presiding over courts where the main local notables (seniorum turba ex concilio de Vurgos) took part; however, in the second example the expression omni concilio de Vurgentium ciuitate points more explicitly to an institutional involvement, rather than the participation of a few prominent individuals. Probably in both cases the composition of the assembly was the same, that is, the local elites of Burgos, but the phrasing of the second suggests a formal representative role of the local concilium, not just the presence of local notables

\footnotetext{
${ }^{27}$ San Millán 3, 176.1 (864). English trans. my own.

${ }^{28}$ Cardeña, 153 (972): Nos totos omnes, concilio pleno de Agusyn, maiores et minores, iubenes et senes; Nos homines uero de Agusyn pernominatos.

29 Albeit for a later period, see the many interesting remarks in I. Alfonso Antón, 'Campesinado y derecho: la vía legal de su lucha (siglos X-XIII)', Noticiario de Historia Agraria, 13 (1997), 15-32.

${ }^{30}$ Cardeña, 36 (941): in prouidentia domni Fredinandi comitis et omnium iudicum et seniorum turbam ex concilio de Vurgos.

31 Cardeña, 151 (972): in presentia de Garsea Fernandiz comite uel omni concilio de Vurgientium ciuitate.
} 
in the count's entourage. Nevertheless, Burgos being the comital see, of all Castilian places, is where one could expect the local council to become occasionally confused with the Count's court. There are, however, examples from rural settlements, such as the lawsuit that was heard in 1022 'in the presence of Rodrigo Muñoz [...] Cid Pérez, Anaya Savariquiz [...] in the council of Camesa Castro'. ${ }^{32}$

\section{Local Council as Collective Actor in the Document}

Although most charters record transactions involving two or more individuals, or (an) individual(s) and one (monastic) institution, in some cases we can see the community acting as a collective party in a legal affair. Local communities are recorded selling, exchanging or donating parts of their collective property, and sometimes it is possible to envisage that such operations were actually a way of settling some sort of dispute or tension. For instance, the aforesaid 972 agreement, by which the whole council of Ausín gave the Count of Castile property in exchange for exemption from public obligations, ${ }^{33}$ might well have derived from a dispute with the neighbouring monastery of Cardeña, to which the count promptly donated the land in question. ${ }^{34} \mathrm{~A}$ similar situation might lie behind a charter of 932, which records the purchase of a portion of grazing land (defesa) by the abbot of San Miguel de Froncea. The council's collective action is clearly expressed: 'and we, the whole council of Arlanzón, that desired and made this charter of purchase, heard it being read and signed it with our own hands in the presence of witnesses from'. The sale is, however, formulated as pact: 'I, Abbot Íñigo made this agreement with the whole college of Arlanzón', which, together with the abundance of spiritual references, is suggestive of an exceptional situation that required the transaction to be expressed in morally compelling language. ${ }^{35}$ Likewise, as seen above, the remarkable case of the council of Villabáscones shows a community that, after freeing from their patronage a monastery, entered in conflict with it and signed in 956 an agreement over water rights that, again, contains a clear expression of the councils' corporate action: 'we, the whole council of Villabáscones, signed...' 36

\section{Local council meeting as the context of legal deeds}

There are a number of cases in which local assemblies are recorded as the context where deeds involving individual actors were effected and/or recorded in script. The council's role-normally expressed as in concilio de $X$ or similar-is to provide public acknowledgement of the transactions effected. For example, in 1033 the noble lady Oneca paid the fine for which a man from Grisaleña was liable for homicide, and the latter in return gave her his property, with the acknowledgement of the local council: 'and by doing this I confirm such testament in the presence and assembly of my

\footnotetext{
32 Santillana2, 31 (1022): in presentia id est Roderico Munni ... Citi Petriz, Annaya Savariquiz, ... in Concilio Camesa Castro.

${ }^{33}$ Cardeña, 153 (972): and many others, the whole council of Ausín, from the lowest to the highest, signed here [et aliorum multorum toto concilio pleno de Agusin, de minimo usque ad maximo, hic rouorabimus].

${ }^{34}$ Cardeña, 157 (972).

35 Cartulary of San Miguel de Froncea, Biblioteca Universitaria de Oviedo, M. 456, fol. 1r-1v: et toto collegio de Arlançone, qui hanc cartam comparationis fecimus, volumus et legente audivimus et manus nostras roboravimus coram testes'; 'Ego Enecus abbas facio conveniencia con toto collegio de Arlançone. See also W. Davies, 'When Gift is Sale: Reciprocities and Commodities in Tenth-Century Christian Iberia', in W. Davies and P. Fouracre (eds), The Languages of Gift in the Early Middle Ages (Cambridge, Cambridge University Press, 2010), pp. 217-37.

${ }^{36}$ Cardeña, 89 (956): omni concilio de Uilla Uascones roborauimus.
} 
neighbours' ${ }^{37}$ At a local scale, most land transactions between private local persons must have had a certain 'public' dimension. Even in the later Middle Ages, land sales or exchanges had to be performed with full publicity, even if the summoning of a council assembly was not needed. ${ }^{38}$ Interestingly, in the 10th-century charters mentions of a local council acting in support of a written deed often refer to aristocratic 'private' affairs (the case cited above might be one such, as besides the local man, Juan, there was Lady Oneca involved). When in 950 the lady Osicia invested her sister María, abbess of San Andrés de Villabilla, as her heiress, the charter was supported by the village council: 'and may this deed have full validity in the council of Villabilla' ${ }^{39}$ In 984 a similar transaction involving members of an aristocratic kindred was enacted 'in the presence of the council of Villafría and of maiorinus Cristóbal, the priest'. ${ }^{40}$ Much more solemnly, in 1030×1031 an agreement between the bishop of Burgos and the monastery of Santillana was witnessed by a representation from the knights of the region (infançones de Asturias) and another from good men from the councils of Camesa and Santillana (et aliorum bonorum ominum de concilio de Camesa, vel de Sancta Iuliana). ${ }^{41}$ Also quite special is a charter from 1032 by which a noblewoman donated property to a man called Nuza as a payment for having negotiated the release of her daughter from the king's prison: 'so that you release mi daughter Doña Froilo from captivity at the palace of the lord King Sancho in Monzón'. The donation was consigned to script in the presence of the council of the town of Cea: 'in concilio zibitas Zeia fuit scripta'. ${ }^{42}$

It seems, therefore, that performing legal deeds in the context of a local assembly was a matter of concern not only for community members, but also for aristocrats who sometimes sought that kind of support for their own affairs. It is not clear, however, why that is explicit in only a minority of places. It could be hypothesised that in strictly local affairs, land transactions could be publicised without need for a formal meeting, while aristocrats had the power to have an assembly summoned for them that would give extra prestige to their deeds. However, importantly, most aristocratic transactions do not actually mention any local assembly, so it remains obscure why in some cases that did happen.

Besides the appearances of councils as parties in a deed, or as the context of other people's deeds, the diplomatic nature of the evidence sometimes has the advantage of showing rural communities acting in a formal capacity as subscribers or witnesses. Although by no means frequent, this is crucially important, as it entails a general recognition of the local councils' legal personality: 'and we, the whole council of Arlanzón, that desired and made this charter of purchase, heard it being read and signed it with our own hands in the presence of witnesses from' (932); ${ }^{43}$ 'we, the whole council of Villabáscones, signed...' (956); ${ }^{44}$ 'and many others, the whole council of

\footnotetext{
37 SanMillán1 198 (1033): Et hoc faciens in presentia et concilio de meos vicinos tali testamentum confirmo.

38 J. Escalona, I. Alfonso and F. Reyes Téllez, 'Arqueología e historia de los paisajes medievales. Apuntes para una agenda de investigación', in R. Garrabou and J. M. Naredo (eds), El paisaje en perspectiva histórica. Formación y transformación del paisaje en el mundo mediterráneo (Zaragoza, Prensas Universitarias de Zaragoza, 2008), pp. 91-116.

${ }^{39}$ Cardeña, 70 (950): et hec scriptura ista plenam abeat firmitatem in concilio de Uilla Albilla.

${ }^{40}$ Cardeña, 192 (981): in presentia de concilio de Uillafrida et maiorino Christoforus presbiter.

${ }^{41}$ Santillana1, 88 (1030-1).

${ }^{42}$ Sahagún2, 433 (1032): pro que saques filia mea domna Froylo de kaptibitate de palatium regis domno Santium de Montesone.

${ }^{43}$ See note 36.

${ }^{44}$ See note 37.
} 
Ausín, from the lowest to the highest, signed here' $(972) ;{ }^{45}$ 'and those who were present in the council of Burgos, signed here' (1029); ${ }^{46}$ 'and the whole council of Grisaleña is witness here' (1033). ${ }^{47}$ Although this represents a role formally different from others, it must be noted that local councils seem to feature as witnesses in those charters in which they also appear as actors or as the general context. This means that the references tend to be concentrated in a very limited number of documents, while most make no explicit mention of them.

\section{Where Did Local Communities Meet?}

The issue of the location of local assemblies in this period is one of the trickiest to explore. We can expect little in this respect from place-names or from archaeological research, while charters only very rarely give hints about where people actually assembled. To start with crossroads, the repeated idea-derived from Isidore's compita - that peasants in the Visigothic period met at crossroads may be hampered, as stated above, by the word's more generic meaning of 'meeting-place'. Furthermore, there is no conclusive indication in the Castilian charters that people in the comital period chose crossroads as a suitable venue for their local councils.

Cemeteries are also often cited as potential meeting-places. True, we know that gatherings, celebrations, festivals and other rituals did take place sometimes in cemeteries, not only in Late Antiquity, but also in the High Middle Ages. In 1055 the Council of Coyanza mentioned the widespread custom of feasting in cemeteries, and sometimes certain archaeological features such as the so-called libation pots and channels have been related to those practices. ${ }^{48}$ Besides, cemeteries are among the few spaces within village sites that can be defined archaeologically as 'public' ${ }^{49}$ However, while holding religious and funerary meetings seems to have been common throughout Castile in the early Middle Ages and beyond, it has not been demonstrated that cemeteries were used for council meetings as a regular practice in any period.

The central and later medieval evidence would strongly support the local church as the preferred venue for council meetings. Not only is there abundant evidence for local councils meeting in the atrium or porch of the local parish church, but there is even more detailed evidence of specific actions, such as oath-taking. For example, in 1289, an inquiry over seigneurial revenues due by the people of Contreras to the abbot of San Pedro de Arlanza was dealt with through the oaths sworn by local people in a church: 'abbot Don Gonzalo went to Contreras, to the church under the elm trees', and took oaths from five men and two old women, 'and the abbot demanded them in the presence of the knights and the good men of the council that these men and women should say the truth about how the revenues [treuderas] that were due to the abbot in

\footnotetext{
${ }^{45}$ See note 34 .

${ }^{46}$ Peña 49 (1029): et quod presentes ibi fuerunt in concilio de Burgus hic roboraverunt.

${ }^{47}$ SanMillán1, 198 (1033): et toto concilio de Ecclesiaselenga testes.

48 A. García Gallo, 'El Concilio de Coyanza. Contribución al estudio del derecho canónico en la Alta Edad Media', Anuario de Historia del Derecho Español, 20 (1950), 275-633; A. Azkarate Garai-Olaun, 'Pervivencias rituales precristianas en las necrópolis del País vasco durante el medievo. Testimonios arqueológicos', in F. J. Fernández Conde (ed.), III Congreso de Arqueología Medieval Española (Oviedo, Universidad de Oviedo, 1989), pp. 483-92.

${ }^{49}$ I thank Alfonso Vigil-Escalera for a most fruitful discussion on this issue.
} 
Contreras should be paid'. ${ }^{50}$ This case suggests that the ritual of oath-taking demanded a church as the proper scenario.

Exactly the same procedure can be detected in the 10th century. In 911 a legal case was judged by Count Gonzalo Téllez in which the witnesses swore the truth of their statements 'upon the holy four Gospels and the relics of San Millán, whose church is located in Gabinea, with our hands upon the altar'. ${ }^{51}$ Likewise, in 936 and 940 two inter-related disputes were settled by the oaths made in the church of Santa María in Sietefinestras. ${ }^{52}$ More explicitly, in 1012 Count Sancho García of Castile sentenced Nuño Álvarez de Melites and Justa de Maturana to swear an oath about the customary exemptions of their community (Nave de Albura), which oath was made in the church of Santa Agadea de Término. ${ }^{53}$ Here the wording seems to imply that the case was heard not in Nave de Albura, but in Término (a district centre) and that the two representatives of Nave were taken to the church nearby to make their oath. All this does not mean that all local meetings needed to be held in or near a church, but, since oath-making was a key element in dispute settlements, having a church at hand would often be important.

Now, the case for local churches as the setting for council assemblies is conditioned by the ongoing debate about the origins of early medieval rural churches in north-western Iberia. The written sources of the Visigothic period mention many churches of different kinds in rural locations, but they also make clear that most rural settlements did not have a church. The so-called Suevic Parish-list, of the 6th century, depicts a two-layered diocesan network comprising episcopal sees (urban) and parish churches located in small towns or major rural settlements, although this did not exclude lesser churches and private chapels. ${ }^{54}$ The excavations of Visigothic-period villages carried out during the last two decades point in the same direction: rural sites normally did not have churches. ${ }^{55}$ Importantly, the density of rural sites of the Visigothic period excavated in the Madrid region in the context of the early 21stcentury building boom allows for a more precise picture. The area is even more relevant because - unlike the north - after the 711 Islamic invasion it remained in the Muslimcontrolled part of Iberia and it underwent a massive change in settlement patterns in the 9th century, which prompted the abandonment of most of those villages. Therefore, in the Madrid area it seems safe to conclude that up to the late 8th century rural sites normally did not have churches. The excavations identify houses, working areas, storage areas, agricultural fields and cemeteries, but not churches.

A similar pattern seems to be valid for the Duero plateau and the north in the Visigothic period, although the density of the archaeological record cannot be compared to that of Madrid. On the other hand, recent research tends to emphasise that many, if not all, of the rural churches of north-western Iberia that were hitherto considered to be

\footnotetext{
50 Arlanza, 160 (1289): 'fue el abbad don Gonzalo en Contreras a la yglesia de iusso de los olmos ... e preguntoles el abbad delante los caballeros e delante otros omes bonos del conzeio, e a estos homes e a estas mugeres que digiessen uerdad de que manera se deuien dar las treuderas del abbad en Contreras'.

${ }^{51}$ Valpuesta, 10 (911). Similar cases in Valpuesta, 11 (919), Puerto, 2 (927), Cardeña, 151 (972).

52 SanMillán2, 191.a.1 (936) and 191.a.2 (940).

${ }^{53}$ SanMillán2, 129.b.1 (1012).

54 P. d. 1. C. Díaz Martínez, 'El Parrochiale Suevum: organización eclesiástica, poder político y poblamiento en la Gallaecia Tardoantigua', in J. Alvar Ezquerra and J. Mangas Manjarrés (eds), Homenaje a José Má Blázquez (Madrid, Ediciones Clásicas, 1998), pp. 35-48.

55 A. Vigil-Escalera Guirado and J. A. Quirós Castillo, 'Early Medieval Rural Societies in North-Western Spain: Archaeological Reflections of Fragmentation and Convergence', in J. Escalona and A. Reynolds (eds), Scale and Scale Change in the Early Middle Ages: Exploring Landscape, Local Society and the World Beyond (Turnhout, Brepols, 2011), pp. 33-60.
} 
of Visigothic date may actually have built in the late 9th or 10th centuries. ${ }^{56}$ Moreover, recent research in the Basque Country has shown that some medieval parish churches overlay ordinary dwelling structures of the usual kind in early medieval villages. This has led J. A. Quirós to argue that churches were latecomers to the peasant settlements, rather than the central foci around which they grew up. ${ }^{57}$

By contrast, the charters from the 9th to 11 th centuries mention large numbers of churches of different kinds, from monasteries to ordinary local churches to hermitic shrines. In the absence of a thorough survey, it would be risky to infer that it was the norm for every village to have at least one church, but it is quite clear that this was frequently the case. The obvious conclusion is that between the end of the Visigothic period and the 10th century there was a key development in the rural landscapes of north-western Iberia consisting of the construction of large numbers of small local churches throughout the territory. At which point this led into the central medieval pattern of parish churches as places for council assemblies is not clear, but it may have been a long process that was well underway in the 10th century, so it makes good sense to think that the meetings mentioned in charters may often have taken place in or near churches, even if this cannot be proven.

\section{Did Local Communities Engage in Meetings at a Supralocal Scale?}

Slim and patchy as it is, the evidence reviewed so far seems enough to make a strong case for the existence of local assemblies in the County of Castile, as well as for defining some of their characteristics. Among the latter, one outstanding feature is that however self-enclosed early medieval village communities might appear, they were far from isolated from the world beyond. Their formal connections with the wider legal environment through their involvement in charter production and in judicial disputes point in that direction as much as the ways in which noble persons sought the support of local assemblies for their deeds. It is thus a fair question to wonder to what extent those assemblies can be considered of strictly local scale.

There are several ways of exploring this question. First, the charter evidence makes clear that it was not unusual (in fact, it might have been the norm in this period) for village communities to have shared rights to commons with neighbouring communities. This becomes especially clear in charters recording how specific stretches of common land were transferred to monastic houses with exclusive access rights, in which case there are usually more or less explicit references to the neighbouring villagers being banned from them. Whenever two or more villages shared rights over commons there must have been decisions to take and disputes to settle, which necessarily called for meetings above the local level. Unfortunately, since in this period such meetings must have been devoted to strictly local affairs, they have left hardly any

\footnotetext{
${ }^{56}$ L. Caballero Zoreda, 'La arquitectura denominada de época visigoda, ¿es realmente tardorromana o prerrománica?', in L. Caballero Zoreda and P. Mateos (eds), Visigodos y Omeyas. Un debate entre la Antigüedad Tardía y la Alta Edad Media (Madrid, CSIC, 2000), pp. 207-48; M. Á. Utrero Agudo, 'LateAntique and Early Medieval Hispanic Churches and the Archaeology of Architecture: Revisions and Reinterpretation of Constructions, Chronologies and Contexts', Medieval Archaeology, 54.1 (2010), 133; Cf. A. Chavarría Arnau, 'Churches and Aristocracies in Seventh-Century Spain: Some Thoughts on the Debate on Visigothic Churches', Early Medieval Europe, 18.2 (2010), 160-74.

57 J. A. Quirós Castillo, 'Las iglesias altomedievales en el País Vasco. Del monumento al paisaje', Studia Historica. Historia Medieval, 29 (2011), 175-205; A. Vigil-Escalera Guirado and J. A. Quirós Castillo, 'Early Medieval Rural Societies in North-Western Spain'; see also I. Martín Viso, 'Paisajes sagrados, paisajes eclesiásticos: de la necrópolis a la parroquia en el centro de la Península Ibérica', Reti Medievali Rivista, 13.2 (2012): http://dx.doi.org/10.6092/1593-2214/362.
} 
trace in the charter corpus, the only exception being disputes like the one that led Count Sancho García de Castilla to define in 1014 the boundaries of the common land to which the villages of Berzosa and Alfania had joint rights. The event took place 'in the assembly of the men of Berzosa and Alfania, that is Ateque Lélez and Juan Sónaz, Armentero Muñoz of Alfania, Don Sancho and Antolín and Munio Mémez, these men being from the council'. ${ }^{58}$ It was therefore only a group of representatives from both villages, but they are mentioned as a single concilium, which seems to indicate that, when gathered for such purposes, two villages could temporarily form a single assembly. It does not follow that such assemblies should take place periodically, but rather whenever the circumstances demanded it. Much later, in the 12th and 13th centuries, when the disputes for grazing rights between neighbouring villages become increasingly frequent, it is usual to find conflicting communities establishing agreements by meeting (normally with some judicial officer, arbitrator or mediator) on the border between their respective territories - a reasonable practice that may well have been in use in the earlier periods, although there is no evidence for it.

Second, within some of the Castilian administrative districts (alfoces), the concilium of the district centre might have had a say in transactions or disputes related to other settlements within the district. This kind of spatial hierarchisation is well attested from the 11th century in the so-called concejos de villa y tierra south of the river Duero, but it is found only extremely rarely in the Castilian county. A precious example from the cartulary of San Miguel de Froncea shows in 932 the collegium of Arlanzón (the centre of an homonymous small district east of Burgos) selling to the abbot of San Miguel a piece of grazing land in Froncea, that is, a different settlement from Arlanzón proper, but which included in its district 'the place that is called Froncea, in the territory of Arlanzón'.59 Similar situations may well have existed elsewhere without leaving trace in the charters. ${ }^{60}$

Third, a different kind of involvement with the supralocal derives from meetings in which political officers, noble persons or high ecclesiastical institutions also took part. As seen above, that sometimes happened within a strictly local framework, as when members of the nobility had their deeds witnessed by local councils, or when the count or his officers held judicial assemblies in ordinary villages. However, there were also occasions in which higher political meetings took place in a locality whose council became thus involved in a further-reaching event. Of course, high political powers could have their meetings in other venues, such as aristocratic or royal palaces, ${ }^{61}$ or major monasteries, ${ }^{62}$ but they sometimes chose to meet in places where the ruler would be

\footnotetext{
${ }^{58}$ Condes, 75 (1014): in concilio de omes de Verezosa et de Alfania id est Atequellellez et Joan Sonnaz, Armentero Monnioz de Alfania, don Sanzo et Antoniano et Monnio Mennez de Verezosa, istos omines de concilio.

${ }^{59}$ Cartulary of San Miguel de Froncea, Biblioteca Universitaria de Oviedo, M. 456, fol. 1r-1v: loco quem vocitant Franuncea in territorio de Arlançone.

${ }^{60}$ On the trend of Castilian charters to override supralocal hierarchies and focus on the local level, see J. Escalona, "De "señores y campesinos" a "poderes feudales y comunidades": Elementos para definir la articulación entre territorio y clases sociales en la Alta Edad Media castellana', in I. Álvarez Borge (ed.), Comunidades locales y poderes feudales en la Edad Media (Logroño, Universidad de La Rioja, 2001), pp. 117-55.

${ }^{61}$ J. Escalona and I. Martín Viso, 'Los palatia, puntos de centralización de rentas en la Meseta del Duero (siglos IX-XI)', in A. Vigil-Escalera, G. Bianchi and J. A. Quirós (eds), Horrea, Barns and Silos: Storage and Incomes in Early Medieval Europe (Bilbao, Universidad del País Vasco, 2013), pp. 103-26.

${ }^{62}$ In 1029 a substantial grant to San Millán de la Cogolla by King Sancho and Queen Jimena of Navarre was effected in situ at the monastery: et alii plures testes qui fuerunt in Sancti Emiliani. See SanMillán1, 186 (1028). A similar setting has been suggested for two donations to San Pedro de Arlanza and San Andrés de Boada made in 937 (Arlanza, 14 and 15), arguably at the monastery of San Pedro de
} 
surrounded not just by his high-status entourage, but also by a representation of the commoners. This usually happened in central places, and most importantly-as seen above - in the city of Burgos, whose local council may have been invested with a sort of symbolic representational role for the whole of the county, so that the council's participation in the count's assembly could represent the whole Castilian people. To end with, there is a most telling expression of the symbolic importance of the Burgos council. In 944 King Ramiro II seized Count Fernán González of Castile, put him in prison, and had him replaced by his son Sancho as ruler of Castile, with the assistance of Count Assur Fernández of Monzón (actually a renowned rival of Fernán González). ${ }^{63}$ The king's effective seizure of control in Castile was accompanied by a mise-en-scéne in Burgos. A Cardeña charter may be the only trace left of a political meeting presided over by the king in which Ramiro II issued what is the only royal donation in the whole 10th-century Castilian corpus. With very significant wording, the king gave to the monastery of Cardeña - the county's main monastery and a major part of the count's power resources - the 'land that hitherto was called the count's apple-orchard (ipsa terra qui condan extitit pumare de comite), by which action he expressed the royal takeover of the count's rights and his capacity to give them away as he pleased - the gift was largely symbolic, since the donated property was actually very small compared to the rest of the comital estates. Also very eloquently, the council of Burgos is mentioned as having received an honorary payment 'because that donation was effected in their assembly': 'And certainly it pleased all the people who dwell together in the city of Burgos that you should give us that honour, as it was in our assembly that this donation was effected'. ${ }^{64}$ The choice of a local-assembly-turned-royal had the extra value of representing a sort of public acknowledgement of the king's dramatic intervention in Castile.

\section{Conclusions}

The above is a preliminary exploration of the issue of local community assemblies in the County of Castile. More detailed research on the charters, together with careful topographical contextualisation of all references to such meetings may shed new light on a subject as important as it is hard to pin down.

Rather than definite conclusions, my survey offers suggestions that could be taken as working hypotheses for a more thorough investigation. It seems safe to state, in the first place, that local communities did meet in Castile to deal with their everyday affairs. The frequency of such meetings is so far impossible to define, while their location is similarly obscure, although an increasing preference for local churches as the venues to celebrate such meetings could be hypothesised as an ongoing trend in the 10th century. In the near future, more intense archaeological research into local churches, especially parish churches, may help illuminate - or rule out - this process.

Such meetings were by nature multi-functional. The range of issues that local councils had to deal with was a varied as the circumstances demanded. However, their

Berlangas, in the context of a high meeting of the Count of Castile with noblemen, bishops and abbots; see J. Escalona, I. Velázquez Soriano and P. Juárez, 'Identification of the Sole Extant Charter Issued by Fernán González, Count of Castile (932-970)', Journal of Medieval Iberian Studies, 4.1 (2012), 259-88.

63 On the political significance of this episode, see J. Escalona, 'In the Name of a Distant King: Representing Royal Authority in the County of Castile, c.900-1038', Early Medieval Europe, 24.1 (2016), 74-102 at 78.

${ }^{64}$ Cardeña, 46 (944): Etenim uero nos omnis populus quoabitantes in Burgientium ciuitate sic nobis bene placuit ut dedissetis nobis honore, propter quod in uestro concilio fuit facta hanc donationem. 
representation in the written records seems to be strongly biased towards those aspects that could be of the greatest interest to the ecclesiastical and aristocratic powers that lay behind the process of charter production and preservation. It seems clear that the affairs that were probably of the greatest local relevance, such as petty crime or small-scale disputes, or, more importantly, the management of commons, are crudely underrepresented-if represented at all-in our records. Conversely, the council's 'diplomatic' roles, as the formal scenario for transactions and agreements and as a collective subscriber or witness is prominent, even if it occurs in a minority of charters. Among the latter, the cases of noble persons - arguably external to the communitywho had their deeds enacted in the context of those local assemblies, probably in search of public recognition, are an outstanding feature that deserves further investigation.

If the details of local assemblies remain hard to grasp, statements about peasant meetings at a supralocal scale can only be highly speculative. Here, comparative work with other Iberian areas may help add some flesh to what presently is no more than bare bones. Local involvement in 'higher political' affairs by means of the leading participation of high-status people, whether for judicial or merely political purposes has also been detected.

A final remark must be made about the political character of local assemblies. This is a view that clearly requires correction. Local council meetings were as political as they could be at the local scale in 10th-century Castile. Dealing with common land, water rights or forests affected immensely the local distribution of wealth and power, as well as mechanisms of internal differentiation. This can only be regarded as political, even if counts and aristocrats hardly took notice of such matters unless they were directly interested in those resources. It will not suffice to define local assemblies as 'locally political', that is, of no political significance beyond the local scale. The political nature of local assemblies was acknowledged by a larger political body. Their participation as a collective actor in legal deeds, their acceptance as witnesses, their desired role as supporters and guarantors of transactions, all suggest that local councils were externally recognised as parts of the functioning of a political system, even if not as complex, defined and formalised as those found in the central medieval sources reveal.

\section{Abbreviations}

Arlanza $=$ Serrano, L. (ed.) 1925, Cartulario de San pedro de Arlanza (antiguo monasterio benedictino), Madrid, Junta para la Ampliación de Estudios-Centro de Estudios Históricos.

Cardeña = Martínez Díez, G. (ed.) 1998, Colección documental del monasterio de San Pedro de Cardeña, Burgos: Caja de Ahorros y Monte de Piedad del Círculo Católico de Obreros.

Condes = Zabalza Duque, M. (ed.), 1998, Colección Diplomática de los Condes de Castilla, Salamanca, Junta de Castilla y León.

Puerto = Abad Barrasús, J. (ed.) 1985, El monasterio de Santa María del Puerto (Santoña), 863-1210, Santander, Institución Cultural de Cantabria, Centro de Estudios Montañeses, Diputación Regional de Cantabria, 1985. 
Sahagún2 = Herrero de la Fuente, M. (ed.) 1988, Colección diplomática del monasterio de Sahagún (857-1230), vol. 2: (1000-1073), León, Centro de Estudios e Investigación 'San Isidoro'.

SanMillán1 = Ubieto Arteta, A. (ed.) 1976, Cartulario de San Millán de la Cogolla (759-1076), Valencia, Anubar.

SanMillán2 = García Andreva, F. (ed.) 2010, El Becerro Galicano de San Millán de la Cogolla. Edición y Estudio, Logroño: Cilengua. Instituto de Orígenes del Español.

Santillana1 = Jusué, E. 1912, Libro de Regla o Cartulario de la Antigua Abadía de Santilla del Mar, Madrid.

Santillana2 = Díez Herrera, C., López Ormazábal, L. and Pérez Bustamante, R. (eds) 1983, Abadía de Santillana del Mar. Colección Diplomática, Santillana del Mar: Fundación Santillana.

Valpuesta = Ruiz Asencio, J. M., Ruiz Albi, I. and Herrero Jiménez, I. M. (eds) 2010, Los Becerros Gótico y Galicano de Valpuesta, 2 vols, Madrid, Real Academia Española-Instituto Castellano y Leonés de la Lengua, 2010. 